\title{
Is serum phosphorus control related to parathyroid hormone control in dialysis patients with secondary hyperparathyroidism?
}

\author{
João M Frazão ${ }^{1 *}$, Johann Braun², Piergiorgio Messa ${ }^{3}$, Bastian Dehmel $^{4}$, Caroline Mattin $^{5}$ and Martin Wilkie ${ }^{6}$
}

\begin{abstract}
Background: Elevated serum phosphorus (P) levels have been linked to increased morbidity and mortality in dialysis patients with secondary hyperparathyroidism (SHPT) but may be difficult to control if parathyroid hormone (PTH) is persistently elevated. We conducted a post hoc analysis of data from an earlier interventional study (OPTIMA) to explore the relationship between PTH control and serum P.

Methods: The OPTIMA study randomized dialysis patients with intact PTH (iPTH) 300-799 pg/mL to receive conventional care alone (vitamin $D$ and/or phosphate binders $[P B] ; n=184)$ or a cinacalcet-based regimen $(n=368)$. For patients randomized to conventional care, investigators were allowed flexibility in using a non-cinacalcet regimen (with no specific criteria for vitamin $\mathrm{D}$ analogue dosage) to attain $\mathrm{KDOQ}{ }^{\mathrm{TM}}$ targets for $\mathrm{PTH}, \mathrm{P}, \mathrm{Ca}$ and $\mathrm{Ca} \times \mathrm{P}$. For those assigned to the cinacalcet-based regimen, dosages of cinacalcet, vitamin D sterols, and PB were optimized over the first 16 weeks of the study, using a predefined treatment algorithm. The present analysis examined achievement of serum P targets ( $\leq 4.5$ and $\leq 5.5 \mathrm{mg} / \mathrm{dL}$ ) in relation to achievement of $\mathrm{PPTH} \leq 300 \mathrm{pg} / \mathrm{mL}$ during the efficacy assessment phase (EAP; weeks 17-23).

Results: Patients who achieved $\mathrm{PPTH} \leq 300 \mathrm{pg} / \mathrm{mL}$ (or a reduction of $\geq 30 \%$ from baseline) were more likely to achieve serum $P$ targets than those who did not, regardless of treatment group. Of those who did achieve iPTH $\leq 300 \mathrm{pg} / \mathrm{mL}$, 43\% achieved $\mathrm{P} \leq 4.5 \mathrm{mg} / \mathrm{dL}$ and $70 \%$ achieved $\mathrm{P} \leq 5.5 \mathrm{mg} / \mathrm{dL}$, versus $21 \%$ and $46 \%$ of those who did not achieve iPTH $\leq 300 \mathrm{pg} / \mathrm{mL}$. Doses of PB tended to be higher in patients not achieving serum P targets. Patients receiving cinacalcet were more likely to achieve $\mathrm{iPTH} \leq 300 \mathrm{pg} / \mathrm{mL}$ than those receiving conventional care ( $73 \%$ vs $23 \%$ of patients). Logistic regression analysis identified lower baseline $\mathrm{P}$, no PB use at baseline and cinacalcet treatment to be predictors of achieving $P \leq 4.5 \mathrm{mg} / \mathrm{dL}$ during EAP in patients above this threshold at baseline.
\end{abstract}

Conclusions: This post hoc analysis found that control of serum P in dialysis patients was better when serum PTH levels were lowered effectively, regardless of treatment received.

Trial registration: Clinicaltrials.gov identifier NCT00110890

\footnotetext{
* Correspondence: jmmdfrazao@netcabo.pt

'Department of Nephrology, Hospital de S. João, Medical School \& Nephrology Research \& Development Unit, University of Porto, Porto, Portugal

Full list of author information is available at the end of the article
} 


\section{Background}

Chronic kidney disease (CKD) is accompanied by progressively impaired metabolism of calcium, phosphorus and vitamin $\mathrm{D}$, eventually leading to secondary hyperparathyroidism (SHPT), a clinical syndrome of abnormal mineral and bone metabolism and extraskeletal calcifications that is associated with an increased risk of bone fractures, cardiovascular morbidity and death $[1,2]$.

As elevated serum parathyroid hormone (PTH), phosphorus and calcium have all been linked with increased morbidity and mortality in dialysis (CKD stage 5D) patients [3-7], the National Kidney Foundation's Kidney Disease Outcomes Quality Initiative (NKF-K/DOQI ${ }^{\mathrm{mm}}\left[\mathrm{KDOQI}^{\mathrm{TM}}\right]$ ) in 2003 recommended stringent targets for intact PTH (iPTH; $150-300 \mathrm{pg} / \mathrm{mL}$ ), calcium $(8.4-9.5 \mathrm{mg} / \mathrm{dL}$ ) and phosphorus $(3.5-5.5 \mathrm{mg} / \mathrm{dL})$ for this population of patients [8]. With increasing awareness of the key contribution of elevated serum phosphorus to vascular calcification and cardiovascular morbidity [3,4,7,9-11], more recent guidelines from the Kidney Disease: Improving Global Outcomes (KDIGO) group have highlighted the importance of tight control of serum phosphorus and calcium. KDIGO suggest that levels as close to normal as possible should be aimed for in dialysis patients and that the choice of pharmacological treatment should be influenced by these parameters [12].

It has long been known that phosphorus loading in experimental renal failure can contribute to the elevated PTH levels and parathyroid gland hyperplasia that characterize SHPT [13]. Much less appreciated is the concept that SHPT-induced dissolution of bone mineral may be a significant contributor to the development of hyperphosphataemia [14], as highlighted in a recent review [15]. A recent KDOQI commentary also noted that PTH-induced mobilization of phosphorus from bone, and potentially other tissues, may contribute to hyperphosphataemia and that this pathophysiological process would not be ameliorated by phosphate binders [16].

Vitamin D sterols and phosphate binders, together with dietary phosphate restriction, have traditionally been the cornerstone of SHPT management. With traditional vitamin D-based treatments there is a trade-off between controlling PTH on one hand and elevating calcium and phosphorus on the other hand, making it difficult to achieve simultaneous control of these parameters. Vitamin D sterols promote intestinal absorption of calcium and phosphorus and, in excess, can mobilize calcium from bone. Thus, excessive calcium loading from calcium-based phosphate binders and high doses of vitamin D sterols can promote hypercalcaemia and hyperphosphataemia, which can necessitate treatment interruptions [17]. This is reflected in the small proportion of dialysis patients who succeed in achieving and maintaining the targets recommended by KDOQI for serum PTH, phosphorus and calcium [18-20].

The calcimimetic agent cinacalcet (Mimpara ${ }^{\circledR} /$ Sensipar $^{\circledR}$, Amgen Inc., Thousand Oaks, CA, USA) has a different mechanism of PTH-lowering action from vitamin $\mathrm{D}$, with opposite effects on serum calcium and phosphorus levels. By enhancing the sensitivity of the parathyroid calciumsensing receptors to extracellular calcium, cinacalcet suppresses PTH synthesis and secretion [21]. When added to a conventional treatment regimen, cinacalcet is effective in lowering serum PTH, phosphorus and calcium levels in dialysis patients [22-26]. The phase 3 OPTIMA (OpenLabel, Randomized Study Using Cinacalcet to Improve Achievement of KDOQI Targets in Patients with EndStage Renal Disease) study showed that a cinacalcet-based regimen can allow reduction of vitamin $\mathrm{D}$ dosage while improving mineral metabolism compared to conventional treatment [26].

We conducted a post hoc analysis of OPTIMA data to explore the relationship between the control of PTH and that of serum phosphorus in dialysis patients with SHPT.

\section{Methods}

\section{OPTIMA methodology}

A detailed description of the OPTIMA study methods has been presented elsewhere [26]. Briefly, haemodialysis and peritoneal dialysis patients with iPTH $300-799 \mathrm{pg} / \mathrm{mL}$, stratified by baseline serum calcium-phosphorus ion product (Ca x P; $>55$ vs $\leq 55 \mathrm{mg}^{2} / \mathrm{dL}^{2}$ ) and baseline vitamin D use, were randomized to receive either a cinacalcet-based regimen or conventional care (vitamin D and/or phosphate binders) in open-label fashion. For patients randomized to conventional care, investigators were allowed flexibility in using a non-cinacalcet regimen (with no specific criteria for vitamin $\mathrm{D}$ analogue dosage) to attain KDOQI targets for iPTH, phosphorus, calcium and $\mathrm{Ca} \times \mathrm{P}$. For those assigned to the cinacalcet-based regimen, dosages of cinacalcet, vitamin D sterols and phosphate binders were optimized over the first 16 weeks, using a predefined treatment algorithm to achieve KDOQI targets.

The starting dose of cinacalcet $30 \mathrm{mg}$ once daily was increased stepwise (maximum $180 \mathrm{mg}$ ) if $\mathrm{iPTH}$ was $>300 \mathrm{pg} / \mathrm{mL}$ (biointact PTH $>150 \mathrm{pg} / \mathrm{mL}$ ), unless precluded by hypocalcaemia (corrected serum calcium $<8.0 \mathrm{mg} / \mathrm{dL}$ ) or adverse events. Cinacalcet dose was to be reduced if $\mathrm{iPTH}$ was $<150 \mathrm{pg} / \mathrm{mL}$ and vitamin D sterols were not being given, or could not be further reduced. If $\mathrm{iPTH}$ was $<150 \mathrm{pg} / \mathrm{mL}$ and/or calcium and phosphorus exceeded KDOQI targets, vitamin D dosage was reduced by approximately $50 \%$, in sequential steps, until a minimum dose was reached (intravenous calcitriol $0.5 \mu \mathrm{g}$, alfacalcidol $1 \mu \mathrm{g}$ or paricalcitol $2 \mu \mathrm{g} 3$ times per week [TIW] or oral calcitriol $0.25 \mu \mathrm{g}$ TIW or alfacalcidol $0.25 \mu \mathrm{g} /$ day). Vitamin D dose 
was increased if iPTH was $>300 \mathrm{pg} / \mathrm{mL}$ on the maximum cinacalcet dose, or in the event of hypocalcaemia not resolving with oral calcium supplementation.

Serum PTH, calcium and phosphorus levels were measured at 2-week intervals throughout the 16-week dose optimization phase and 7-week efficacy assessment phase (EAP). The means of these parameters during the EAP were used to evaluate efficacy. PTH levels measured by biointact assay were multiplied by 1.95 to convert to iPTH values [27]. To facilitate comparison of vitamin D doses, a relative vitamin $\mathrm{D}$ dose was calculated by converting dosages into a multiple of the protocol-defined minimum dose for each vitamin $\mathrm{D}$ analogue (see values above) [26].

For names and addresses of all ethical approval committees that granted approval for OPTIMA see Additional file 1.

\section{Present analysis}

For the present analysis, we used a relatively low serum phosphorus cut off of $4.5 \mathrm{mg} / \mathrm{dL}$, in line with the new recommendations from KDIGO [12], as well as the earlier KDOQI target of $5.5 \mathrm{mg} / \mathrm{dL}$ [8]. For iPTH we used a cut off of $300 \mathrm{pg} / \mathrm{mL}$, the upper limit of the range recommended by KDOQI [8]: this also falls within the broader range suggested by KDIGO [12].

The proportion of patients with serum phosphorus $\leq 4.5$ or $\leq 5.5 \mathrm{mg} / \mathrm{dL}$ during the EAP was compared for patients who did, versus those who did not, achieve the iPTH target of $\leq 300 \mathrm{pg} / \mathrm{mL}$ during the EAP. This was done for both treatment groups combined and additionally by treatment group (conventional care or cinacalcet).

The proportion of patients with serum phosphorus $\leq 4.5$ or $\leq 5.5 \mathrm{mg} / \mathrm{dL}$ during the EAP was also compared for patients who did, versus those who did not, achieve a serum PTH reduction $\geq 30 \%$ during the EAP, for both treatment groups combined and additionally by treatment group.

The following were also evaluated:

- Serum phosphorus, corrected calcium and alkaline phosphatase activity, at baseline and EAP, and changes from baseline to EAP, according to PTH target achievement category at EAP.

- Usage of cinacalcet, vitamin D, calcium- and aluminium-based phosphate binders and sevelamer, at baseline and end of EAP, within each PTH and serum phosphorus target category defined above.

Analysis was performed on the full analysis set (all randomized patients). A last value carried forward imputation (LVCF) method was used for patients who did not have iPTH, phosphorus or calcium values measured during the EAP. Patients who still had missing PTH or phosphorus values during the EAP after imputation (i.e. no post-baseline value) and patients with missing serum phosphorus values at baseline $(\mathrm{N}=13)$ were excluded from this analysis. Key analyses were repeated based on observed data (without imputation). If vitamin $\mathrm{D}$ dose was missing at the end of the EAP due to early study discontinuation, the vitamin $\mathrm{D}$ dose at the time of discontinuation was used. Likewise, if alkaline phosphatase was missing at the end of the EAP, the last postbaseline value was carried forward.

Pearson's chi-squared test was used to compare achievement of serum phosphorus targets by PTH target achievement category (iPTH $\leq$ versus $>300 \mathrm{pg} / \mathrm{mL}$ ) and magnitude of $\mathrm{PTH}$ reduction (PTH reduction $\geq 30 \%$ versus decrease $<30 \%$ or increase during the EAP). The paired $t$-test was used to assess changes in serum phosphorus and calcium and vitamin D doses from baseline to the EAP.

Logistic regression analysis was performed to explore variables associated with achievement of serum phosphorus $\leq 4.5 \mathrm{mg} / \mathrm{dL}$. Variables considered were serum phosphorus; iPTH; alkaline phosphatase; use of phosphate binders, and vitamin $\mathrm{D}$ at baseline, age, country and randomized treatment. Variables that were found to be significant $(\mathrm{P}<0.05)$ in univariate analysis were included in a multivariate analysis, using a stepwise iterative procedure.

\section{Results}

\section{Patients}

Results of OPTIMA are published elsewhere [26]. 184 patients were randomized to conventional care alone and 368 to cinacalcet: demographic characteristics and baseline laboratory values were similar between the treatment groups. A total of $82 \%$ of patients in the conventional care group and $76 \%$ of those randomized to cinacalcet completed the EAP. Reasons for early discontinuation included adverse events ( $1 \%$ conventional care vs $7 \%$ cinacalcet), withdrawal of consent ( $2 \%$ vs $4 \%$ ), death (3\% vs $3 \%$ ), renal transplantation (3\% vs 2\%) and other causes (7\% vs 5\%) [26]. Cinacalcet was more effective than conventional care in controlling PTH: mean (SD) iPTH levels decreased from 505 (147) $\mathrm{pg} / \mathrm{mL}$ at baseline to 264 (168) $\mathrm{pg} / \mathrm{mL}$ during the EAP (mean change $-46 \%$ ) in the cinacalcet arm versus little change in the conventional care group (from 507 [143] to 519 [281] pg/mL; mean change $+2 \%)$. Similarly, mean (SD) serum phosphorus decreased from 5.5 (1.7) $\mathrm{mg} / \mathrm{dL}$ at baseline to 5.1 (1.6) $\mathrm{mg} / \mathrm{dL}$ during the EAP in the cinacalcet group, but was $5.4(1.5) \mathrm{mg} / \mathrm{dL}$ at both time points in the conventional care group [26].

Thirteen OPTIMA patients were excluded from the present analysis on the basis of missing phosphorus and/ or PTH values, leaving a total of 539 patients $(n=357$ cinacalcet; $n=182$ conventional care). Patients showed biochemical evidence of high bone turnover, as indicated 
by a mean (SD) iPTH level of 505 (142) [median 487] $\mathrm{pg} / \mathrm{mL}$ and alkaline phosphatase activity of 127 (92) [median 97] U/L at baseline.

Relationship of PTH control to serum phosphorus control Patients who achieved iPTH $\leq 300 \mathrm{pg} / \mathrm{mL}$ at the EAP were more likely to achieve either serum phosphorus $\leq 4.5$ or $\leq 5.5 \mathrm{mg} / \mathrm{dL}$ at the EAP than those who did not $(\mathrm{P}<0.001$ for both phosphorus cut offs) [Table 1]. Among those who achieved the PTH target, the proportion of patients with serum phosphorus $\leq 4.5 \mathrm{mg} / \mathrm{dL}$ increased from $29 \%$ at baseline to $43 \%$ at EAP. However, among those who did not achieve the PTH target, the proportion of patients with serum phosphorus $\leq 4.5 \mathrm{mg} / \mathrm{dL}$ remained low $(24 \%$ at baseline and $21 \%$ at EAP).A similar pattern was seen with the serum phosphorus $\leq 5.5 \mathrm{mg} / \mathrm{dL}$ cut off: the proportion of patients within this target increased from $57 \%$ to $70 \%$ between baseline and EAP among those who achieved the PTH target but showed little change from baseline to EAP in those who did not achieve PTH target (52 vs 46\%) [Table 1]. Results were similar when using observed data, without imputation of missing values during the EAP.

Patients who failed to achieve the PTH target had little change in serum phosphorus $(p=0.19)$, whereas those who achieved the PTH target had a significant decrease $(\mathrm{P}<0.001)$. Baseline serum phosphorus levels were similar in these two subgroups of patients [Table 1; Figure 1]. Figure 1 shows that the decrease in mean serum phosphorus in those who achieved the PTH target occurred shortly after starting treatment and was sustained throughout the study.

All patients, except for two who were enrolled in error, had $\mathrm{iPTH}>300 \mathrm{pg} / \mathrm{mL}$ at baseline: $27 \%$ and $55 \%$ of patients had serum phosphorus $\leq 4.5$ and $\leq 5.5 \mathrm{mg} / \mathrm{dL}$, respectively. Baseline iPTH was slightly higher in patients with baseline serum phosphorus $>4.5 \mathrm{mg} / \mathrm{dL}$ versus those with serum phosphorus $\leq 4.5 \mathrm{mg} / \mathrm{dL}$ (mean [SD] 513 [141] vs 482 [144] pg/mL; median 501 vs 457 $\mathrm{pg} / \mathrm{mL}$ ). A similar pattern was seen for the $5.5 \mathrm{mg} / \mathrm{dL}$ cut off (baseline mean [SD] 524 [140] vs 490 [143] pg/ mL; median 507 vs 465 pg/mL).

A total of 41 patients (23\%) who received conventional care and 259 (73\%) patients who received cinacalcet achieved iPTH $\leq 300 \mathrm{pg} / \mathrm{mL}$ (data not shown). Figure 2 shows the proportion of patients achieving serum phosphorus targets by achievement of PTH endpoints, separated by treatment group. Within each treatment group, achievement of serum phosphorus targets was more common in those achieving the PTH target.

Achievement of serum phosphorus targets was also more common in those who achieved a serum PTH reduction $\geq 30 \%$ at EAP $(\mathrm{P}<0.001)$, as shown in Table 2 . Results were similar when using observed data, without imputation of missing values during the EAP.

Multivariate logistic regression analysis showed that variables associated with the probability of achieving serum phosphorus $\leq 4.5 \mathrm{mg} / \mathrm{dL}$ during EAP were baseline serum phosphorus, baseline iPTH, baseline phosphate binder use and randomized treatment. Patients with lower baseline serum phosphorus and iPTH, those not taking phosphate binders at baseline and those randomized to cinacalcet were more likely to achieve serum phosphorus $\leq 4.5 \mathrm{mg} / \mathrm{dL}$ during the EAP. When analysis was restricted to patients with serum phosphorus $>4.5 \mathrm{mg} / \mathrm{dL}$ at baseline, variables associated with the probability of achieving serum phosphorus $\leq 4.5 \mathrm{mg} / \mathrm{dL}$ during EAP were baseline serum phosphorus, baseline phosphate binder use and randomized treatment. Results were similar when analysis was based on observed serum phosphorus values during the EAP without imputation, although phosphate binder use was no longer significant.

Table 1 Serum phosphorus (P) category and mean serum $P$ at baseline and after treatment (efficacy assessment phase; EAP) by iPTH achievement category during EAP

\begin{tabular}{lll}
\hline & iPTH $\leq \mathbf{3 0 0} \mathbf{~ p g} / \mathbf{m L}$ at EAP $(\mathbf{N}=\mathbf{3 0 0})$ & iPTH $>\mathbf{3 0 0} \mathbf{~ p g} / \mathbf{m L}$ at EAP $(\mathbf{N}=\mathbf{2 3 9})$ \\
\hline Serum P category, no of patients (\%) & & $58(24)$ \\
\hline$\leq 4.5 \mathrm{mg} / \mathrm{dL}$ at baseline & $88(29)$ & $50(21)$ \\
\hline$\leq 4.5 \mathrm{mg} / \mathrm{dL}$ at EAP & $130(43)^{*}$ & $125(52)$ \\
\hline$\leq 5.5 \mathrm{mg} / \mathrm{dL}$ at baseline & $172(57)$ & $111(46)$ \\
\hline$\leq 5.5 \mathrm{mg} / \mathrm{dL}$ at EAP & $209(70)^{*}$ & $5.5(0.10)$ \\
\hline Serum P mean $(S E)$ absolute values $(\mathrm{mg} / \mathrm{dL})$ & & $5.6(0.10)$ \\
\hline Baseline & $5.5(0.10)$ & $0.1(0.09)$ \\
\hline EAP & $4.9(0.09)$ & 0.19
\end{tabular}

*P $<0.001$ vs subgroup with $\mathrm{iPTH}>300 \mathrm{pg} / \mathrm{mL}$ at EAP, Pearson chi-squared test. Last value carried forward imputation (LVCF) was used for patients who did not have $\mathrm{iPTH}$ or phosphorus values measured during the EAP.

**Paired $t$-test.

SE: standard error. 


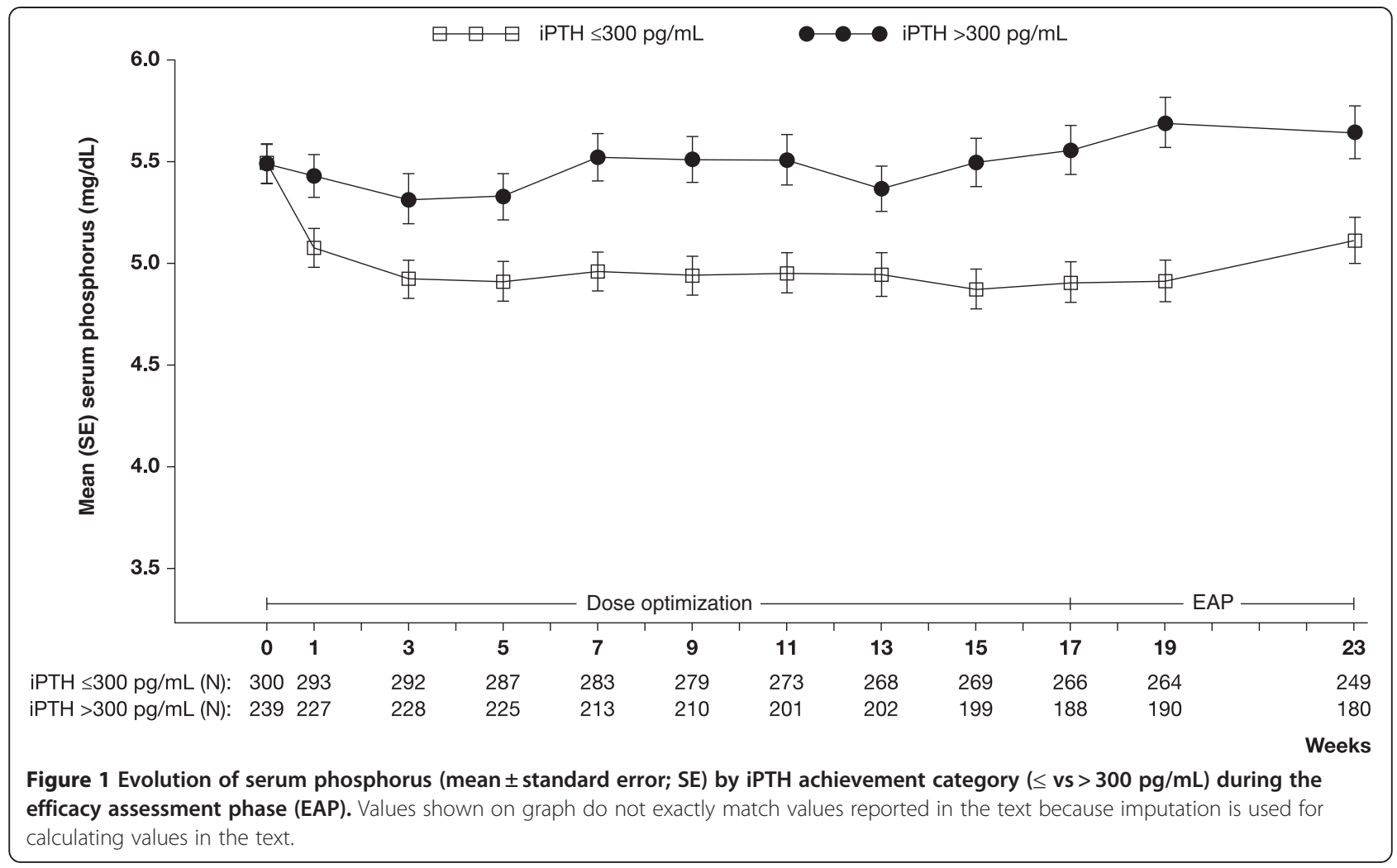

\section{Serum calcium and alkaline phosphatase}

Serum corrected calcium levels were higher in patients who did not achieve the PTH target, both at baseline and EAP. These showed a small but statistically significant decrease $(\mathrm{P}<0.001)$ in both PTH target achievement categories (Table 3). In patients who received conventional care, mean serum calcium was slightly increased $(+0.3 \mathrm{mg} / \mathrm{dL})$ in those with $\mathrm{iPTH} \leq 300 \mathrm{pg} / \mathrm{mL}$ and unchanged in those with $\mathrm{iPTH}>300 \mathrm{pg} / \mathrm{mL}$, at EAP. However, in those who received cinacalcet, mean serum calcium was decreased at EAP in both $\mathrm{iPTH}$ achievement categories $(-0.7$ and $-0.8 \mathrm{mg} / \mathrm{dL}$, respectively; data not shown).

Mean (SE) alkaline phosphatase activity at baseline was 125 (5.4) U/L $(\mathrm{n}=242)$ in patients who met the PTH target and $132(8.8) \mathrm{U} / \mathrm{L}(\mathrm{n}=144)$ in patients who did not meet target. Comparison of baseline and EAP values showed a decrease in both subgroups: mean (SE) -15 (3.4) U/L with PTH $\leq 300 \mathrm{pg} / \mathrm{mL}(\mathrm{n}=215)$ and -11 (5.8) U/L with PTH $>300 \mathrm{pg} / \mathrm{mL}(\mathrm{n}=125)$ at EAP.

\section{Cinacalcet, vitamin D and phosphate binders}

As reported previously [26], approximately two-thirds of patients in each treatment group were receiving vitamin D sterols at baseline and approximately $90 \%$ were receiving phosphate binders. Use of vitamin $\mathrm{D}$ increased in the conventional care group (from $66 \%$ of patients at baseline to $81 \%$ of patients at the end of the study), but showed little change in the cinacalcet group (from $68 \%$ to $73 \%$ of patients). Among patients receiving vitamin $\mathrm{D}$ at baseline, the mean relative dose decreased by $22 \%$ in cinacalcet-treated patients from baseline to week 23 , but was virtually unchanged ( $3 \%$ increase) in those receiving conventional care. Cinacalcet-treated patients also required less sevelamer and aluminum-based binders but more calcium-based binders [26].

Table 4 shows mean doses of cinacalcet, vitamin D (relative doses) and phosphate binders at baseline and EAP by iPTH and serum phosphorus target category. Within both PTH strata, doses of cinacalcet and phosphate binders tended to be higher in patients who were failing to meet serum phosphorus targets, compared with those who did achieve these targets [Table 4].

The relationship of vitamin D use to serum phosphorus achievement was less consistent, but patients who were failing to meet the PTH target were receiving higher vitamin $\mathrm{D}$ doses [Table 4]. There was a significant increase in mean relative vitamin D dose, from 1.6 at baseline to 1.8 at the end of the EAP, in patients not achieving the $\mathrm{iPTH}$ target (mean change 0.2; $\mathrm{p}=0.04$ ). In those achieving the $\mathrm{PPTH}$ target, mean relative vitamin D dose decreased, from 1.6 to 1.4 , although this change was not statistically significant (mean change $-0.1 ; \mathrm{p}=0.18$ ). Figure 3 shows a divergence in mean relative vitamin D dose between the two PTH target 


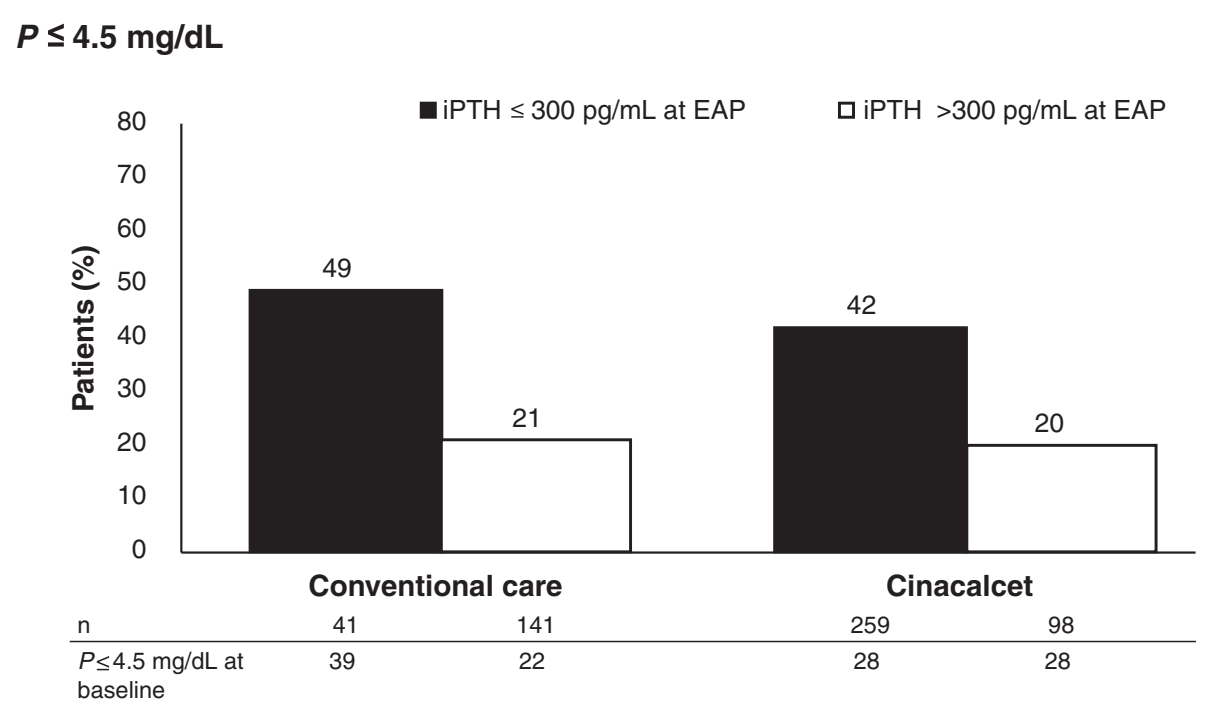

\section{$P \leq 5.5 \mathrm{mg} / \mathrm{dL}$}

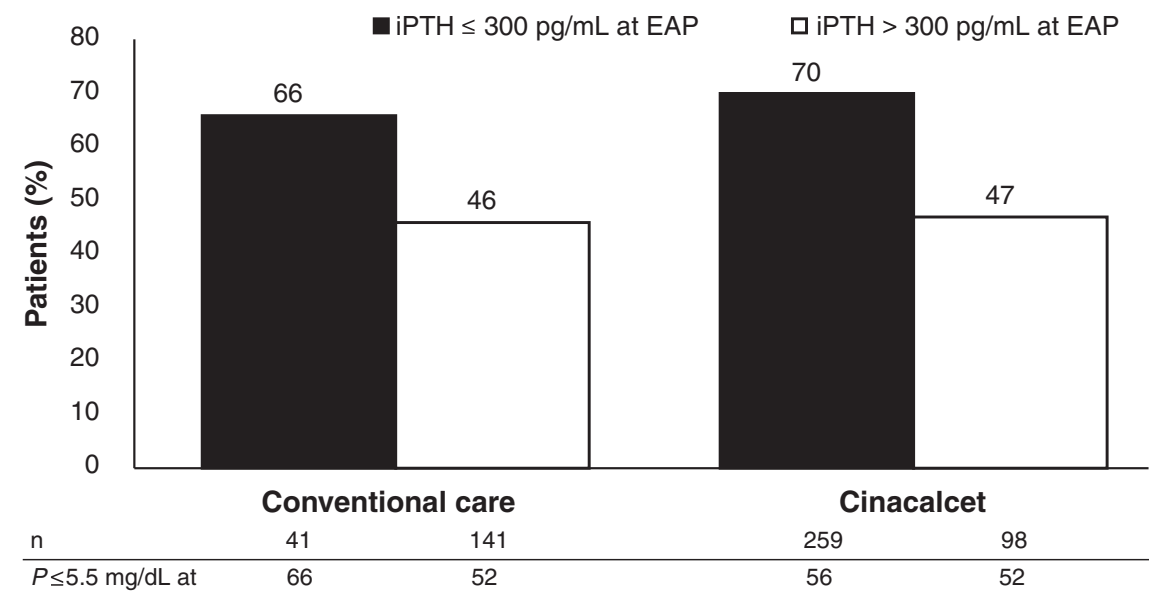

Figure 2 Proportion of patients with serum phosphorus (P) (a) $\leq 4.5$ and (b) $\leq 5.5 \mathrm{mg} / \mathrm{dL}$ by iPTH achievement category after treatment with cinacalcet or conventional care. Figures show \% of patients with P control ( $\leq 4.5$ or $\leq 5.5 \mathrm{mg} / \mathrm{dL}$ ) within each PTH achievement category during the efficacy assessment phase (EAP).

achievement categories during the EAP, although it must be noted that patient numbers decreased between baseline and EAP.

\section{Discussion}

The present post hoc analysis of data from OPTIMA [26] showed that serum phosphorus was better controlled

Table 2 Serum phosphorus (P) category at baseline and after treatment (efficacy assessment phase; EAP) by magnitude of PTH reduction at EAP

\begin{tabular}{lll}
\hline & PTH reduction $\geq \mathbf{3 0 \%}$ at EAP $(\mathbf{N}=\mathbf{3 2 6})$ & PTH reduction $<30 \%$ or increase at EAP (N= 213) \\
\hline$P \leq 4.5 \mathrm{mg} / \mathrm{dL}$ at baseline, $\mathrm{n}(\%)$ & $90(28)$ & $56(26)$ \\
\hline $\mathrm{P} \leq 4.5 \mathrm{mg} / \mathrm{dL}$ at EAP & $131(40)^{*}$ & $49(23)$ \\
\hline$P \leq 5.5 \mathrm{mg} / \mathrm{dL}$ at baseline & $182(56)$ & $115(54)$ \\
\hline$P \leq 5.5 \mathrm{mg} / \mathrm{dL}$ at EAP & $222(68)^{*}$ & $98(46)$ \\
\hline
\end{tabular}

*P $<0.001$ vs subgroup with PTH reduction $<30 \%$ or increase at EAP, Pearson chi-squared test. Last value carried forward imputation (LVCF) was used for patients who did not have iPTH or phosphorus values measured during the EAP. 
Table 3 Mean (SE) corrected serum calcium at baseline and after treatment (efficacy assessment phase; EAP) by iPTH target achievement during EAP

\begin{tabular}{lll}
\hline Calcium, $\mathbf{m g} / \mathbf{d L}$ & $\mathbf{i P T H} \leq \mathbf{3 0 0} \mathbf{~ p g} / \mathbf{m L}$ at EAP $(\mathbf{N}=\mathbf{3 0 0})$ & $\mathbf{i P T H}>\mathbf{3 0 0} \mathbf{~ p g} / \mathbf{m L}$ at EAP $(\mathbf{N}=\mathbf{2 3 9})$ \\
\hline Baseline & $9.6(0.04)[298]$ & $9.8(0.05)[236]$ \\
\hline EAP & $9.1(0.05)[300]$ & $9.5(0.05)[239]$ \\
\hline Change from baseline to EAP & $-0.5(0.05)[298]$ & $-0.3(0.05)[236]$ \\
\hline p-value* & $<0.001$ & $<0.001$ \\
\hline
\end{tabular}

*Paired $t$-test. Last value carried forward imputation (LVCF) was used for patients who did not have iPTH or calcium values measured during the EAP.

SE: standard error.

when PTH was lowered effectively, whether patients received cinacalcet or standard treatment. However, those receiving cinacalcet (two-thirds of patients) were more likely to achieve iPTH $\leq 300 \mathrm{pg} / \mathrm{mL}$ than those receiving conventional treatment ( $73 \%$ vs $23 \%$ of patients). In the subgroup of patients who achieved iPTH $\leq 300 \mathrm{pg} / \mathrm{mL}$ at EAP, serum phosphorus levels decreased significantly and more than $40 \%$ achieved serum phosphorus $\leq 4.5 \mathrm{mg} / \mathrm{dL}$. The decrease in serum phosphorus occurred shortly after starting treatment and was sustained throughout the

Table 4 Usage and dose of cinacalcet, phosphate binders (mg/day) and vitamin D (relative doses)* by PTH and P subgroup at baseline and the end of the efficacy assessment phase (EAP)

\begin{tabular}{|c|c|c|c|c|}
\hline \multicolumn{5}{|l|}{ a. Target $P \leq 4.5 \mathrm{mg} / \mathrm{dL}$} \\
\hline \multirow[t]{2}{*}{ Mean (SE) dose [\% of patients] } & \multicolumn{2}{|c|}{ iPTH $\leq 300 \mathrm{pg} / \mathrm{mL}^{* *}$} & \multicolumn{2}{|c|}{ iPTH > $300 \mathrm{pg} / \mathrm{mL}$} \\
\hline & $\mathrm{P} \leq 4.5 \mathrm{mg} / \mathrm{dL}$ & $\mathrm{P}>4.5 \mathrm{mg} / \mathrm{dL}$ & $\mathrm{P} \leq 4.5 \mathrm{mg} / \mathrm{dL}$ & $P>4.5 \mathrm{mg} / \mathrm{dL}$ \\
\hline BASELINE & - & - & $N=146$ & $N=393$ \\
\hline Ca-based binders & - & - & 1989 (215) [41] & $1883(121)[47]$ \\
\hline Sevelamer & - & - & 4137 (297) [48] & 4876 (156) [55] \\
\hline Vitamin D & - & - & $1.5(0.1)[70]$ & $1.6(0.1)[67]$ \\
\hline Al-based binders & - & - & $1874(222)[18]$ & 2450 (188) [20] \\
\hline EAP & $N=130$ & $N=170$ & $N=50$ & $N=189$ \\
\hline Cinacalcet & $44(4)[79]$ & 54 (4) [84] & 81 (15) [33] & $96(8)[34]$ \\
\hline Ca-based binders & 1844 (197) [63] & $2331(202)[71]$ & $1888(234)[36]$ & 2218 (267) [48] \\
\hline Sevelamer & 4192 (428) [33] & 4973 (250) [53] & 4345 (480) [50] & 4830 (256) [63] \\
\hline Vitamin D & $1.3(0.1)[70]$ & $1.6(0.2)[77]$ & $2.0(0.3)[83]$ & $1.8(0.1)[78]$ \\
\hline Al-based binders & $2876(605)[8]$ & 2335 (319) [16] & 2469 (557) [19] & 2837 (369) [18] \\
\hline \multicolumn{5}{|l|}{ b. Target $P \leq 5.5 \mathrm{mg} / \mathrm{dL}$} \\
\hline \multirow[t]{2}{*}{ Mean(SE) dose [\% of patients] } & \multicolumn{2}{|c|}{ iPTH $\leq 300 \mathrm{pg} / \mathrm{mL}^{* *}$} & \multicolumn{2}{|c|}{$\mathrm{iPTH}>300 \mathrm{pg} / \mathrm{mL}$} \\
\hline & $\mathrm{P} \leq 5.5 \mathrm{mg} / \mathrm{dL}$ & $P>5.5 \mathrm{mg} / \mathrm{dL}$ & $P \leq 5.5 \mathrm{mg} / \mathrm{dL}$ & $P>5.5 \mathrm{mg} / \mathrm{dL}$ \\
\hline BASELINE & - & - & $N=297$ & $N=242$ \\
\hline Ca-based binders & - & - & 1880 (142) [45] & 1944 (159) [45] \\
\hline Sevelamer & - & - & 4434 (195) [48] & 4960 (196) [58] \\
\hline Vitamin D & - & - & $1.6(0.1)[70]$ & $1.5(0.1)$ [65] \\
\hline Al-based binders & - & - & 1995 (199) [14] & 2518 (215) [25] \\
\hline$\overline{E A P}$ & $N=209$ & $N=91$ & $N=111$ & $N=128$ \\
\hline Cinacalcet & 46 (3) [83] & $60(6)[81]$ & 85 (10) [31] & 99 (10) [36] \\
\hline Ca-based binders & 1975 (156) [64] & 2458 (298) [76] & 2079 (313) [47] & 2238 (326) [44] \\
\hline Sevelamer & 4454 (279) [40] & 5168 (344) [57] & 4175 (347) [51] & 5103 (292) [68] \\
\hline Vitamin D & $1.4(0.1)[74]$ & $1.6(0.3)[74]$ & $2.1(0.2)[82]$ & $1.6(0.2)[77]$ \\
\hline Al-based binders & 2462 (410) [7] & $2463(384)[24]$ & 2859 (519) [12] & 2709 (390) [23] \\
\hline
\end{tabular}

*Relative dose: dosage is based on conversion of each dose a patient received into a multiple of the defined minimum dose for a particular sterol: IV calcitriol $=0.5 \mu \mathrm{g} 3$ times per week (TIW), IV alfacalcidol $=1 \mu \mathrm{g} \mathrm{TIW}$, IV paricalcitol $=2 \mu \mathrm{g}$ TIW, oral calcitriol $=0.25 \mu \mathrm{g}$ TIW, oral alfacalcidol $=0.25 \mu \mathrm{g}$ once daily. Patients not receiving vitamin $\mathrm{D}$ at a timepoint are counted as having a zero dose at that timepoint. For Ca-or Aluminium-based $\mathrm{P}$ binders and sevelamer, dose is based on those actually receiving these agents.

**Patients were required to have iPTH $300-799 \mathrm{pg} / \mathrm{mL}$ at baseline but two patients with PTH $<300 \mathrm{pg} / \mathrm{mL}$ were enrolled in error. For simplicity, data for these patients are not shown separately.

SE: standard error. 


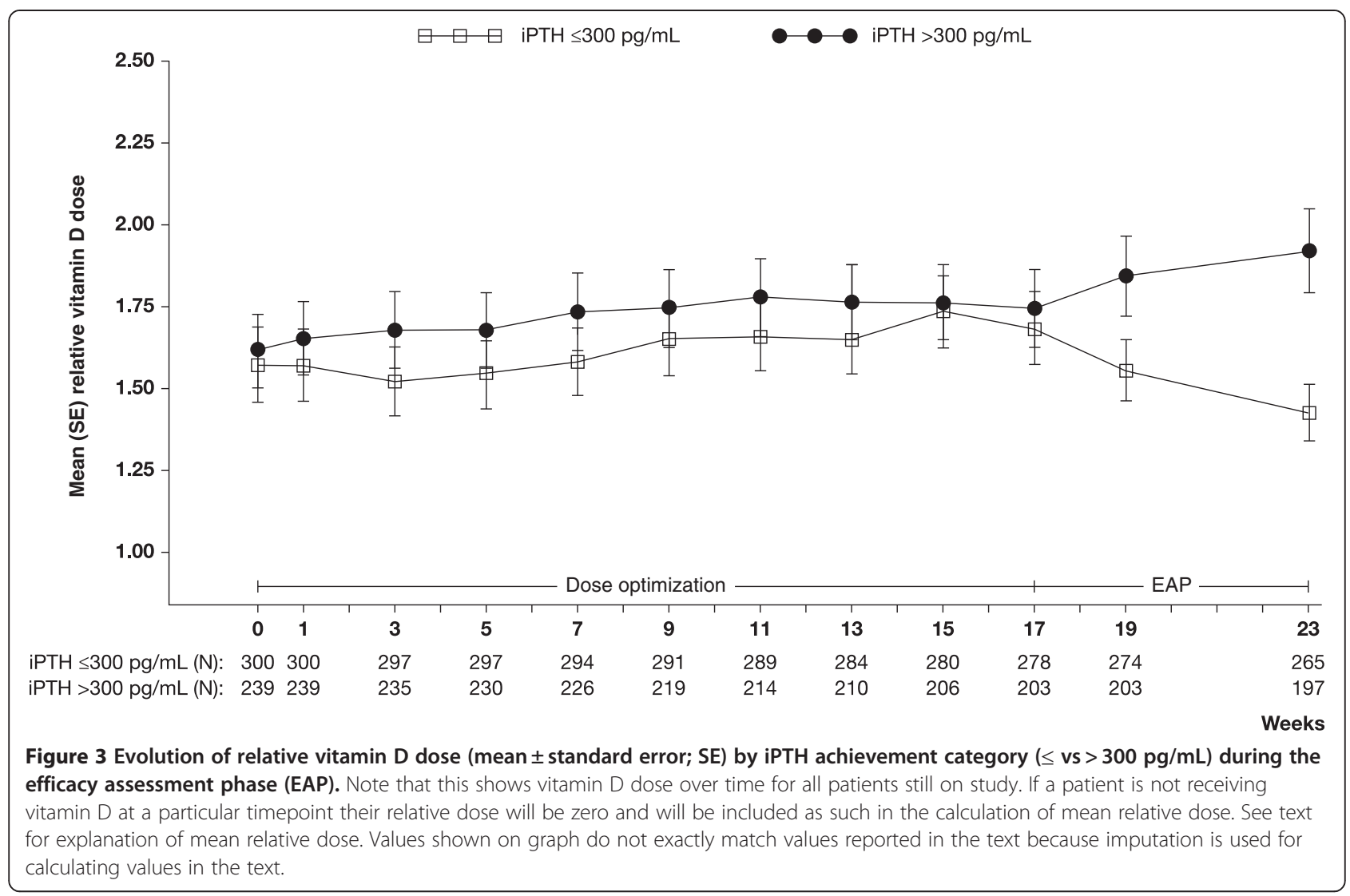

study. In contrast, the subgroup who did not achieve the PTH target did not show any improvement in serum phosphorus between baseline and EAP, either in terms of mean absolute levels or the proportion of patients within serum phosphorus targets. Only $21 \%$ had serum phosphorus $\leq 4.5 \mathrm{mg} / \mathrm{dL}$ at EAP.

Achievement of serum phosphorus targets was also more common in those who had a serum PTH reduction $\geq 30 \%$ at EAP. Logistic regression analysis identified lower baseline serum phosphorus, no phosphate binder use at baseline and cinacalcet treatment to be predictors of achieving serum phosphorus $\leq 4.5 \mathrm{mg} / \mathrm{dL}$ during EAP in patients who were above this threshold at baseline.

Improvement in serum phosphorus control was not related to increased phosphate binder usage overall. Indeed, usage of phosphate binders tended to be higher in patients who were failing to meet serum phosphorus targets [Table 4]. There was a significant increase in relative vitamin $\mathrm{D}$ dose in patients with uncontrolled PTH but this was not accompanied by a significant increase in serum phosphorus. On the other hand, a significant decrease in serum phosphorus was seen in those with controlled PTH, although a significant decrease in relative vitamin D dose was not seen in this subgroup. These findings suggest that changes in vitamin $\mathrm{D}$ and phosphate binders are less important than changes in PTH in this setting.

Serum corrected calcium levels were higher in patients who did not achieve the PTH target, both at baseline and EAP. It could be argued that a less suppressible PTH is accompanied by a higher serum calcium set-point and hence a higher serum calcium level. Alternatively, less suppressible PTH might have induced clinicians to use higher doses of vitamin D, with a consequent increase in serum calcium. Patients showed biochemical evidence of high bone turnover at baseline, as indicated by their elevated PTH and alkaline phosphatase values. Alkaline phosphatase activity decreased by a similar amount in the two PTH achievement categories.

As this is a post-hoc analysis, it is difficult to establish causality for the serum phosphorus changes observed in OPTIMA. There were no checks for dietary control and compliance in the study and nutritional markers were not studied. Thus, we cannot exclude the possibility that improved dietary compliance could have played a part in the serum phosphorus reduction in some patients. Bone biopsies were not performed in OPTIMA and bone turnover markers other than PTH and alkaline phosphatase were not studied. Moreover, as analyses 
were conducted at local laboratories, assay methods were not standardized.

PTH is known to mobilize calcium and phosphorus from bone [14] and evidence to support the hypothesis that improved PTH control leads to improved serum phosphorus control is accumulating. Substantial decreases in serum phosphorus levels have been observed in patients who undergo parathyroidectomy for advanced SHPT [28-30]. It is common to see decreases in the early postoperative period, with sustained improvement in phosphorus control thereafter. In addition, it has recently been shown that direct infusion of PTH leads to a significant rise in serum phosphorus in dialysis patients, especially in those with high-turnover bone disease [31]. This increase can be observed after several hours of infusion and during the fasting state, supporting a primary role for $\mathrm{PTH}$-induced bone resorption as the mechanism for the increased phosphorus levels. Moreover, analysis of PTH evolution over time also shows that increases in PTH are associated with an increase in serum phosphorus and vice versa [32]. These findings raise the question as to whether increased serum phosphorus levels are stimulating parathyroid gland function, or whether hyperparathyroidism is leading to worsened phosphorus control via increased bone resorption. It is likely that both of these pathophysiological mechanisms operate in a vicious cycle in endstage renal disease. Indeed, recent studies have documented the efficacy of cinacalcet in reducing increased total and bone-specific alkaline phosphatase [33].

The lower serum phosphorus cut off that we explored $(\leq 4.5 \mathrm{mg} / \mathrm{dL})$ is in line with new recommendations from KDIGO to aim for near-normal serum phosphorus levels in dialysis patients [12]. Although KDIGO have recommended a lowering of the phosphorus target range, they have also relaxed the PTH target range [12] for a variety of reasons, including the observation that a significant proportion of patients with iPTH in the $150-300 \mathrm{pg} / \mathrm{mL}$ range have low-turnover bone disease [34]. A recent cohort study in 22,937 dialysis patients showed that consistent control of markers of bone metabolism and disease within KDOQI targets is a strong predictor of survival in this population [19]. Compared with those who achieved target for three variables (PTH, phosphorus and calcium), the risk of death was $51 \%, 35-39 \%$ and $15-21 \%$ higher in patients who achieved none, one and two of these targets. For each marker, maintaining within target for one calendar quarter or less was associated with a higher mortality risk than achieving control for four quarters: $16 \%$ higher for calcium and $34 \%$ for $\mathrm{PTH}$, rising to $62 \%$ higher for phosphorus [19]. Other data published since the KDOQI guidelines have shown improved outcomes in dialysis patients if PTH is controlled [35-37]. For instance, a case control study based on the US Renal Data System found a 32\% reduction in hip fracture risk after parathyroidectomy [35]. Coronary artery calcification score in dialysis patients was also found to be independently associated with iPTH levels in the ADVANCE study [38]. In the CORES study in 16,173 patients, both elevated and low serum levels of calcium, phosphorus and PTH were associated with increased mortality [36].

\section{Conclusions}

Our findings suggest that in dialysis patients with biochemical evidence of high-turnover bone disease, serum phosphorus control may be linked to PTH control: control of serum phosphorus was more difficult in patients with poorly controlled PTH. Further research is warranted to clarify these findings.

\section{Additional file}

Additional file 1: List of ethics committees for OPTIMA study.

\section{Competing interests}

J. Frazao has been a scientific consultant for, and received lecture fees from, Amgen and Genzyme. He has participated in advisory boards for Amgen, Genzyme, Abbott and Vifor. J. Braun has received honoraria from Amgen and Genzyme and participated in advisory boards for Amgen. P. Messa has given lectures supported by Amgen, Janssen-Cilag, Abbott, Novartis and Roche and participated in advisory boards for Amgen, Abbott and Novartis. M. Wilkie has given lectures supported by Amgen, Baxter and Fresenius, received honoraria from Amgen, Baxter, Fresenius and Shire and participated in advisory boards for Amgen, Baxter, Ineos and Shire. He has also participated in research funded by Amgen. B. Dehmel and C. Mattin are employees of Amgen. Amgen were involved in the design and conduct of the OPTIMA study and the present analysis and provided funding for both. Amgen staff had the opportunity to review the present manuscript.

\section{Authors' contributions}

This analysis was conceptualized by JF, BD and CM. JF, JB, PM and MW were investigators in the original OPTIMA study. CM provided the statistical analysis. All authors participated in the drafting and final approval of the manuscript.

\section{Acknowledgements}

We would like to thank the OPTIMA investigators, including A Albertazzi, P Altieri, P Altmann, S Al-Sarraf, M Andre, U Bahner, C Baldamus, A Balducci, M Becker, A Bock, W Boesken, D Bokemeyer, J Bommer, J Bonal, K Bouman, J Bradley, C Cascone, G Colussi, JM Cruz, J Cruz, J De Meester, N De Santo, M Dhaene, B Draganov, KU Eckardt, A Fernstrom, A Ferreira, R Fiedler, J Floege, P Fröhling, G Fuiano, M Galicia, L Gesualdo, M Girndt, R Gokal, K Gondolf, T González, H Graf, S Grosser, EC Hagen, M Heydenreich, H Holzer, E Honkanen, E Hübel, A Hutchison, N Ibrahim, E Imbasciati, R Jofre, MG Koopman, J Kovarik, R Kramar, KML Leunissen, JD Lippert, G Liuzzo, G Lonnemann, V Lorenzo, G Martín, PY Martin, A Martín-Malo, GJ Mayer, A McLean, G Mellotte, T Meyer, A Morawietz, GA Müller, J Navarro, P Neves, J Olivares, J Paßfall, P Pai, A Palma, P Peeters, P Ponce, A Procaccini, HP Rau, B Riedl, S Roe, LC Rump, JA Sánchez Tomero, M Salvadori, A Santoro, HJ Schmidt-Gürtler, E Scheuermann, A Schleser, H Schneider, H Seidel, G Splendiani, A Stahl-Nilsson, A Stalteri, B Stegmayer, HK Stummvoll, E Svarstad, M Traub, D Uehlinger, R Valentin, G Villa, A Voßkühler, RP Wüthrich. The OPTIMA study was sponsored by Amgen Inc, Thousand Oaks, CA, USA We would also like to thank Julia Balfour, Medical Writer, Dundee, Scotland and Caterina Hatzifoti of Amgen (Europe) $\mathrm{GmbH}$ for assistance with writing of this manuscript, which was supported by Amgen (Europe) $\mathrm{GmbH}$. 


\section{Author details}

'Department of Nephrology, Hospital de S. João, Medical School \& Nephrology Research \& Development Unit, University of Porto, Porto, Portugal. ${ }^{2} \mathrm{KHz}$ Kuratorium fur Dialyse und Nieren transplantation, Nurnberg, Germany. ${ }^{3}$ Fondazione IRCCS Ospedale Maggiore Policlinico Milano, Milan, Italy. ${ }^{4}$ Amgen Europe GmbH, Zug, Switzerland. ${ }^{5}$ Amgen Ltd, Cambridge, UK. ${ }^{6}$ Sheffield Kidney Institute, Sheffield Teaching Hospitals NHS Foundation Trust, Sheffield, UK

\section{Received: 5 April 2012 Accepted: 28 July 2012}

Published: 3 August 2012

\section{References}

1. Slatopolsky E, Brown A, Dusso A: Pathogenesis of secondary hyperparathyroidism. Kidney Int/ 1999, 73:S14-19.

2. Moe S, Drueke T, Cunningham J, Goodman W, Martin K, Olgaard K, Ott S, Sprague S, Lameire N, Eknoyan G: Definition, evaluation, and classification of renal osteodystrophy: a position statement from Kidney Disease: Improving Global Outcomes (KDIGO). Kidney Int/ 2006, 69(11):1945-1953.

3. Block GA, Hulbert-Shearon TE, Levin NW, Port FK: Association of serum phosphorus and calcium $\mathrm{x}$ phosphate product with mortality risk in chronic hemodialysis patients: a national study. Am J Kidney Dis 1998 31(4):607-617

4. Block GA, Klassen PS, Lazarus JM, Ofsthun N, Lowrie EG, Chertow GM: Mineral metabolism, mortality, and morbidity in maintenance hemodialysis. J Am Soc Nephrol 2004, 15(8):2208-2218.

5. Ganesh SK, Stack AG, Levin NW, Hulbert-Shearon T, Port FK: Association of elevated serum $\mathrm{PO}(4), \mathrm{Ca} \times \mathrm{PO}(4)$ product, and parathyroid hormone with cardiac mortality risk in chronic hemodialysis patients. J Am Soc Nephrol 2001, 12(10):2131-2138.

6. Tentori F, Blayney MJ, Albert JM, Gillespie BW, Kerr PG, Bommer J, Young EW, Akizawa T, Akiba T, Pisoni RLRobinson BM, Port FK: Mortality risk for dialysis patients with different levels of serum calcium, phosphorus, and PTH: the Dialysis Outcomes and Practice Patterns Study (DOPPS). Am J Kidney Dis 2008, 52(3):519-530.

7. Young EW, Albert JM, Satayathum S, Goodkin DA, Pisoni RL, Akiba T, Akizawa T, Kurokawa K, Bommer J, Piera L, Port FK: Predictors and consequences of altered mineral metabolism: the Dialysis Outcomes and Practice Patterns Study. Kidney Int/ 2005, 67(3):1179-1187.

8. National Kidney Foundation: K/DOQI clinical practice guidelines for bone metabolism and disease in chronic kidney disease. Am J Kidney Dis 2003 42(4 Suppl 3):1-201.

9. Jono S, McKee MD, Murry CE, Shioi A, Nishizawa Y, Mori K, Morii H, Giachelli CM: Phosphate regulation of vascular smooth muscle cell calcification. Circulation Res 2000, 87(7):E10-17.

10. Kanbay M, Goldsmith D, Akcay A, Covic A: Phosphate - the silent stealthy cardiorenal culprit in all stages of chronic kidney disease: a systematic review. Blood Purif 2009, 27(2):220-230.

11. Mathew S, Tustison KS, Sugatani T, Chaudhary LR, Rifas L, Hruska KA: The mechanism of phosphorus as a cardiovascular risk factor in CKD. J Am Soc Nephrol 2008, 19(6):1092-1105.

12. Disease K: Improving Global Outcomes (KDIGO) CKD-MBD Work Group: KDIGO Clinical practice guidelines for the diagnosis, evaluation, prevention, and Treatment of Chronic Kidney Disease - Mineral and Bone Disorder (CKD-MBD). Kidney Int/ 2009, 76(suppl. 113):S1-S130.

13. Drake TG, Albright F, Castleman B: Parathyroid Hyperplasia in Rabbits Produced by Parenteral Phosphate Administration. J Clin Invest 1937 16(2):203-206.

14. Raisz LG: Bone Resorption in Tissue Culture. Factors Influencing the Response to Parathyroid Hormone. J Clin Invest 1965, 44:103-116.

15. Hruska KA, Mathew S, Lund R, Qiu P, Pratt R: Hyperphosphatemia of chronic kidney disease. Kidney Int/ 2008, 74(2):148-157.

16. Uhlig K, Berns JS, Kestenbaum B, Kumar R, Leonard MB, Martin KJ, Sprague SM, Goldfarb S: KDOQI US commentary on the 2009 KDIGO Clinical Practice Guideline for the Diagnosis, Evaluation, and Treatment of CKD-Mineral and Bone Disorder (CKD-MBD). Am J Kidney Dis 2010, 55(5):773-799.

17. Moe SM, Drueke TB: Management of secondary hyperparathyroidism: the importance and the challenge of controlling parathyroid hormone levels without elevating calcium, phosphorus, and calcium-phosphorus product. AmJ Nephrol 2003, 23(6):369-379.
18. Arenas MD, Alvarez-Ude F, Gil MT, Soriano A, Egea JJ, Millan I, Amoedo ML, Muray S, Carreton MA: Application of NKF-K/DOQI Clinical Practice Guidelines for Bone Metabolism and Disease: changes of clinical practices and their effects on outcomes and quality standards in three haemodialysis units. Nephrol Dial Transplant 2006, 21(6):1663-1668.

19. Danese MD, Belozeroff V, Smirnakis K, Rothman KJ: Consistent control of mineral and bone disorder in incident hemodialysis patients. Clin J Am Soc Nephrol 2008, 3(5):1423-1429.

20. Young EW, Akiba T, Albert JM, McCarthy JT, Kerr PG, Mendelssohn DC, Jadoul M: Magnitude and impact of abnormal mineral metabolism in hemodialysis patients in the Dialysis Outcomes and Practice Patterns Study (DOPPS). Am J Kidney Dis 2004, 44(5 Suppl 3):34-38.

21. Nemeth EF, Steffey ME, Hammerland LG, Hung BC, Van Wagenen BC, DelMar EG, Balandrin MF: Calcimimetics with potent and selective activity on the parathyroid calcium receptor. Proc Nat Acad Sci USA 1998, 95(7):4040-4045.

22. Goodman WG, Hladik GA, Turner SA, Blaisdell PW, Goodkin DA, Liu W, Barri YM, Cohen RM, Coburn JW: The Calcimimetic agent AMG 073 lowers plasma parathyroid hormone levels in hemodialysis patients with secondary hyperparathyroidism. J Am Soc Nephrol 2002, 13(4):1017-1024.

23. Block GA, Martin KJ, de Francisco AL, Turner SA, Avram MM, Suranyi MG, Hercz G, Cunningham J, Abu-Alfa AK, Messa P, Coyne DW, Locatelli F, Cohen RM, Evenepoel P, Moe SM, Fournier A, Braun J, McCary LC, Zani VJ, Olson KA, Drueke TB, Goodman WG: Cinacalcet for secondary hyperparathyroidism in patients receiving hemodialysis. New Engl J Med 2004, 350(15):1516-1525.

24. Quarles LD, Sherrard DJ, Adler S, Rosansky SJ, McCary LC, Liu W, Turner SA, Bushinsky DA: The calcimimetic AMG 073 as a potential treatment for secondary hyperparathyroidism of end-stage renal disease. J Am Soc Nephrol 2003, 14(3):575-583.

25. Lindberg JS, Culleton B, Wong G, Borah MF, Clark RV, Shapiro WB, Roger SD, Husserl FE, Klassen PS, Guo MD, Albizem MB, Coburn JW: Cinacalcet $\mathrm{HCl}$, an oral calcimimetic agent for the treatment of secondary hyperparathyroidism in hemodialysis and peritoneal dialysis: a randomized, double-blind, multicenter study. J Am Soc Nephrol 2005, 16(3):800-807

26. Messa P, Macario F, Yaqoob M, Bouman K, Braun J, Von Albertini B, Brink H, Maduell F, Graf H, Frazao JM, Bos WJ, Torregrosa V, Saha H, Reichel H, Wilkie M, Zani VJ, Molemans B, Carter D, Locatelli F: The OPTIMA study: assessing a new cinacalcet (Sensipar/Mimpara) treatment algorithm for secondary hyperparathyroidism. Clin J Am Soc Nephrol 2008, 3(1):36-45.

27. Martin KJ, Juppner H, Sherrard DJ, Goodman WG, Kaplan MR, Nassar G, Campbell P, Curzi M, Charytan C, McCary LC, Guo MD, Turner SA, Bushinsky DA: First- and second-generation immunometric PTH assays during treatment of hyperparathyroidism with cinacalcet $\mathrm{HCl}$. Kidney Int 2005 68(3):1236-1243

28. Peters BS, Moyses RM, Jorgetti V, Martini LA: Effects of parathyroidectomy on bone remodeling markers and vitamin $\mathrm{D}$ status in patients with chronic kidney disease-mineral and bone disorder. Int Urol Nephrol 2007 39(4):1251-1256.

29. Mazzaferro S, Pasquali M, Farcomeni A, Vestri AR, Filippini A, Romani AM Barresi G, Pugliese F: Parathyroidectomy as a therapeutic tool for targeting the recommended NKF-K/DOQI ranges for serum calcium, phosphate and parathyroid hormone in dialysis patients. Nephrol Dial Transplant 2008, 23(7):2319-2323.

30. Conti-Freitas LC, Foss-Freitas MC, Lucca $\sqcup$, da Costa JA, Mamede RC, Foss MC: Dynamics of parathyroid hormone secretion after total parathyroidectomy and autotransplantation. World J Surg 2009, 33(7):1403-1407.

31. Wesseling-Perry K, Harkins GC, Wang HJ, Elashoff R, Gales B, Horwitz MJ, Stewart AF, Juppner $H$, Salusky IB: The calcemic response to continuous parathyroid hormone (PTH)(1-34) infusion in end-stage kidney disease varies according to bone turnover: a potential role for PTH(7-84). J Clin Endocrinol Metab 2010, 95(6):2772-2780.

32. Kilpatrick RD, Gill KS, Block GA: [SA-PO2403] Exploring the Relationship between Temporal Trends in PTH, P and Ca in HD Patients [abstract presented at the American Society of Nephrology Annual Meeting Denver, Colorado, November 16-21, 2010].

33. Shigematsu T, Akizawa T, Uchida E, Tsukamoto Y, Iwasaki M, Koshikawa S: Long-term cinacalcet $\mathrm{HCl}$ treatment improved bone metabolism in Japanese hemodialysis patients with secondary hyperparathyroidism. Am J Nephrol 2009, 29(3):230-236. 
34. Barreto FC, Barreto DV, Moyses RM, Neves KR, Canziani ME, Draibe SA, Jorgetti V, Carvalho AB: K/DOQI-recommended intact PTH levels do not prevent low-turnover bone disease in hemodialysis patients. Kidney Int 2008, 73(6):771-777.

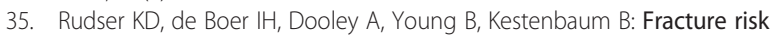
after parathyroidectomy among chronic hemodialysis patients. J Am SoC Nephrol 2007, 18(8):2401-2407.

36. Naves-Diaz M, Passlick-Deetjen J, Guinsburg A, Marelli C, Fernandez-Martin $J$, Rodriguez-Puyol D, Cannata-Andia JB: Calcium, phosphorus, PTH and death rates in a large sample of dialysis patients from Latin America. The CORES Study. Nephrol Dial Transplant 2011, 26(6):1938-47.

37. Floege J, Kim J, Ireland E, Chazot C, Drueke T, de Francisco A, Kronenberg F, Marcelli D, Passlick-Deetjen J, Schernthaner G, Fouqueray B, Wheeler DC: Serum iPTH, calcium and phosphate, and the risk of mortality in a European haemodialysis population. Nephrol Dial Transplant 2011, 26(6):1948-55.

38. Floege J, Raggi P, Block GA, Torres PU, Csiky B, Naso A, Nossuli K, Moustafa M, Goodman WG, Lopez N, Downey G, Dehmel B, Chertow GM: Study design and subject baseline characteristics in the ADVANCE Study: effects of cinacalcet on vascular calcification in haemodialysis patients. Nephrol Dial Transplant 2010, 25(6):1916-1923.

doi:10.1186/1471-2369-13-76

Cite this article as: Frazão et al:: Is serum phosphorus control related to parathyroid hormone control in dialysis patients with secondary hyperparathyroidism?. BMC Nephrology 2012 13:76.

\section{Submit your next manuscript to BioMed Central and take full advantage of:}

- Convenient online submission

- Thorough peer review

- No space constraints or color figure charges

- Immediate publication on acceptance

- Inclusion in PubMed, CAS, Scopus and Google Scholar

- Research which is freely available for redistribution 